\title{
CRIOPRESERVAÇÃO DE SEMENTES DO PANTANAL
}

\section{CRYOPRESERVATION OF PANTANAL SEEDS}

\author{
Carolina de Faria Cabral Paes Pereira e Barros ${ }^{1}$ \\ Petterson Baptista da Luz ${ }^{2}$ \\ Marcos Antônio da Silva Júnior ${ }^{3}$ \\ Severino de Paiva Sobrinho ${ }^{4}$ \\ Carolina Moreira de Medeiros ${ }^{5}$ \\ Nilo Leal Sander 6
}

Submetido: 17/08/2021 / Aprovado: 26/08/2021 / Publicado: 31/10/2021.

\begin{abstract}
Resumo
A biodiversidade que compõe a flora brasileira possui grande riqueza e diversidade de espécies, entretanto, as florestas vem sofrendo ao longo dos anos com mudanças abruptas nos padrões da composição e abundância das espécies. Existe uma preocupação no meio científico, para o desenvolvimento de pesquisas que visem a conservação dos recursos genéticos vegetais nos biomas brasileiros. Dessa forma, objetivou-se com este trabalho desenvolver protocolos de conservação para sementes de duas espécies florestais do bioma Pantanal, por meio do armazenamento em nitrogênio líquido $\left(\mathrm{NL}_{2}\right)$. $\mathrm{O}$ experimento foi distribuído em delineamento inteiramente casualizado, com 2.200 sementes para cada espécie, compondo 10 tratamentos, sendo a TP - Testemunha Padrão com dosagem 0 de crioprotetor e sem imersão em $\mathrm{NL}_{2}$, a Testemunha (T.) com dosagem 0 de crioprotetor, com imersão em $\mathrm{NL}_{2}$ e quatro variações de concentração de sacarose $(0,29,0,58,0,87$ e $1,16 \mathrm{M})$ e dimetilsulfoxido-DMSO $(5,10,15$ e $20 \%$ ) em solução. As sementes foram mergulhadas e mantidas nas soluções crioprotetoras e posteriormente embaladas e armazenadas em $\mathrm{NL}_{2}$ por 120 horas. Foram avaliados a porcentagem de germinação, índice de velocidade de germinação, porcentagem de emergência, índice de velocidade de emergência, comprimentos parte aérea e raiz da plântula, massas secas
\end{abstract}

\footnotetext{
1 Engenheira Florestal, Mestre. Programa de Pós-graduação em Genética e Melhoramento de Plantas Universidade do Estado de Mato Grosso, Cáceres-MT, 78200-000, Brasil. E-mail: carolinna.ef@gmail.com

2 Professor Doutor. Departamento de Agronomia, Laboratório de Sementes e Plantas Ornamentais, Universidade do Estado de Mato Grosso, Cáceres-MT, 78200-000, Brasil. E-mail: petterbaptista@yahoo.com.br

${ }^{3}$ Biólogo, Mestre. Programa de Pós-graduação em Genética e Melhoramento de Plantas - Universidade do Estado de Mato Grosso, Cáceres-MT, 78200-000, Brasil. E-mail: marcosjuniorbio@gmail.com

${ }^{4}$ Professor Doutor. Departamento de Agronomia, Laboratório de Sementes e Plantas Ornamentais, Universidade do Estado de Mato Grosso, Cáceres-MT, 78200-000, Brasil. E-mail: paivasevero@unemat.br

${ }^{5}$ Graduanda em Agronomia. Departamento de Agronomia, Laboratório de Sementes e Plantas Ornamentais, Universidade do Estado de Mato Grosso, Cáceres-MT, 78200-000, Brasil. E-mail: karol_medeyros91@hotmail.com

${ }^{6}$ Biólogo, Doutor. Programa de Pós-graduação em Biodiversidade e Biotecnologia da Amazônia Legal - Rede BIONORTE - Universidade do Estado de Mato Grosso, Cáceres-MT, 78200-000, Brasil. E-mail: nilo.sander@unemat.br
} 
da parte aérea e raiz e massa seca total. A partir dos resultados observados, pode-se afirmar que para todas as espécies estudadas o armazenamento das sementes em $\mathrm{NL}_{2}$ sem o uso de soluções crioprotetoras é viável.

Palavras-chave: Armazenamento; Germinação; Vigor; Crioprotetor.

\begin{abstract}
The biodiversity, which constitutes the Brazilian flora, presents great richness and diversity of species, however, the forests have been suffering over the years with abrupt changes in the composition patterns and abundance of species. There is a concern in the scientific field with the development of researches, which aim at the conservation of plant genetic resources in Brazilian biomes. Thus, the objective of this study was to develop conservation protocols for seed of two forest species of Pantanal biome, by means of storage in liquid nitrogen $\left(\mathrm{NL}_{2}\right)$. The experiment was conducted in a completely randomized design, with 2200 seeds of each species, totalizing 10 treatments: the TP - Standard Witness with 0 cryoprotectant dosage and without immersion in $\mathrm{NL}_{2}$; The $\mathrm{T}$ - witness, with 0 cryoprotectant dosage, and with immersion in $\mathrm{NL}_{2}$ and four variations of sucrose concentration $(0,29,0,58,0,87$, and 1,16 M) and dymethylsulfoxide-DSMO $(5,10,15$ and $20 \%)$ in solution. The seeds were immersed and maintained in cryoprotective solutions and subsequently packed and stored in $\mathrm{NL}_{2}$ for 120 hours. The percentage of germination, germination speed index, emergency percentage, emergence speed index, shoot length and seedling root length, dry shoot, root mass and total dry mass were evaluated. According to the observed results, it can be affirmed that considering all the studied species, the seeds storage in $\mathrm{NL}_{2}$ without the use of cryoprotectant solutions is viable.
\end{abstract}

Palavras-chave: storage; germination; vigor; cryoprotectant.

\title{
INTRODUCTION
}

Pantanal is an important biome in the Upper Paraguay basin, extending through the States of Mato Grosso and Mato Grosso do Sul, being understood as responsible for the connection and transition between the Tropical Rain Forests, Cerrados, Bolivian Chacos and the Southern Forests (Forzza, et al, 2014). It is also seen as accountable for preserving natural richness of great ecological value such as Aroeira (Myracrodruon urundeuva Allem), Cambará (Vochysia divergens Pohl) and the Piuvas (Handroanthus $\mathrm{sp}$ ) in the most different formations.

Taking into account the importance of RGV (plant genetic resources) for both industry and ecosystem dynamics, research have been increasingly concerned with the development of studies and actions in order to conserver RGB (biological genetic resources) in Brazilian biomes, such as the establishment of germplasm banks (BG), seed bank (BS) and field collections (COSTA, 2009).

For Wetzel et al (2003), the storage and the conservation of seeds, or other types of $\mathrm{RGV}$, can be understood as an alternative to guarantee genetic diversity, and to allocate the conserved material for research in genetic improvement programs of activities related to the recovery of degraded areas, reforestation or in commercial plantations, ensuring the plant genetic variability and the perpetuation of the species. Still, according to the authors, the seed, while RGV, can be understood as part of the plant that is able to survive the maximum time with the minimum of physiological activity. So that, when it is intended to conserve a resource 
through seed storage, attention should be paid mainly to the physiological characteristics that may interfere with the longevity of the material of interest.

Among the most varied techniques used for conservation, cryopreservation is considered one of the most suitable for the ex situ conservation of plant germplasm, allowing the storage of biological materials in liquid nitrogen $\left(\mathrm{NL}_{2}\right)$ at $-196^{\circ} \mathrm{C}$ or in nitrogen $(\mathrm{N})$ at $150^{\circ} \mathrm{C}$ for long periods of time, maintaining their genetic stability and causing the least amount of physiological damage to the material (ENGELMANN, 2011).

In the process of cryopreservation, there are cases in which it is necessary to prepare the structure of the plant tissue to be preserved. Therefore, the application of substances or drugs that can minimize the damages caused by freezing and thawing becomes essential in certain species (Molina et al, 2006). The most commonly used solutions are dimethylsufoxide (DSMO), glycerol, ethylene glycol, methanol, propylene glycol and sucrose (Salomão, 2002). However, cryoprotectants may become toxic and may cause irreversible damage to plant cells (SAKAI, 1990).

Santos and Salomão (2010) comment that it is fundamentally important to understand and adapt the protocols using cryopreservation techniques when it is desired to work with the storage of material in ultra-low temperatures. Thus, the objective of this work is to develop conservation protocols for seeds of Myracrodruon urundeuva Allem and Astronium fraxinifolium Schott, through storage in liquid nitrogen.

\section{MATERIAL AND METHODS}

The experiment was developed in the Laboratory of Seeds and Ornamental Plants and Vegetation House of the Departament of Agronomy of the State University of Mato GrossoMT (UNEMAT), located in the Univesity Cit y of Caceres, in the state of Mato Grosso.

Seeds of Myracrodruon urundeuva Allem and Astronium fraxinifolium Schott were purchased by requesting the lots commercialized by Caiçara Seeds, located in the city of Brejo Alegre, in the state of São Paulo. The two lots came with a classification of $70 \%$ germination, $70 \%$ viability and $90 \%$ purity. After the arrival of the material, it was processed in order to select the units which were free of imperfections and damages, and that could cause the unfeasibility of the lots. Afterwards, the seeds were packed in aluminum envelopes and kept in a cold room $\left(7^{\circ} \mathrm{C}+/-3^{\circ} \mathrm{C}\right)$ for 7 days until the treatments were started.

In order to verify the degree of moisture in the lots, the seeds were submitted to the humidity test by means of the forced air circulation oven at $105^{\circ} \mathrm{C}\left(+/-3^{\circ} \mathrm{C}\right)$, situation in which two samples were taken from each lot of 25 seeds, according to the recommendations of the Regulation for Seed Analysis - RAS (Brazil, 2009), being the degree of moisture calculated by the mathematical expression:

$$
\text { Degree of humidity }(\mathrm{U} \%)=\frac{100 \times(\mathrm{Pi}-\mathrm{pf})}{\mathrm{Pi}-\mathrm{t}} \times 100
$$

$\mathrm{Pi}=$ initial weight, container weight + moist seed weight; $\mathrm{pf}=$ final weight, container weight + dry seed weight; $\mathrm{t}=$ tare, container weight.

A total of 2200 seeds was used for each species, totalizing 10 treatments being: Standard control, dosage 0 of cryoprotectant and without immersion in $\mathrm{NL}_{2}$ (T.P.); Control dosage 0 of cryoprotectant, with immersion in $\mathrm{NL}_{2}$ (T.); $0.29 \mathrm{M}$ sucrose in solution (T1); $0.58 \mathrm{M}$ sucrose in solution (T2); $0.87 \mathrm{M}$ sucrose (T3); $1.16 \mathrm{M}$ sucrose in solution (T4); $5 \%$ DMSO in solution (T5); 10\% DMSO in solution (T6); DMSO 15\% in solution (T7); and DMSO 20\% in 
solution (T8). After division by treatment, the seeds were dipped and kept in the cryoprotective solutions for a period of 3 hours at a controlled temperature of $25^{\circ} \mathrm{C}$, then removed and accommodated on the bench for drying at room temperature for 12 hours.

The freezing process was performed by the vitrification method, in which the seeds were packaged in hermetically sealed containers shaped as envelopes, composed by three layers (polyethylene, aluminum and polyethylene), in order to prevent the exchange of moisture with the environment. Then, they were identified by treatment, sealed and immediately stored in $\mathrm{NL}^{2}$ for a period of 120 hours.

For the thawing, the seeds still packed were placed into a water bath, at $37^{\circ} \mathrm{C}$, and then deposited on the stand as a way to meet the room temperature (DECRUSE et al., 1999). The moisture level of each treatment was again verified after the cryopreservation process using forced air chamber and desiccator with silica gel, following the recommendations of Medeiros (2003) for orthodox seeds, with 5-7\% b.u.

The seed distribution for the germination and vigor tests consisted of a completely randomized design (DIC), with four replications of 25 seeds for each treatment.

For the germination test, the seeds were accommodated into transparent acrylic boxes with a lid measuring $11 \mathrm{X} 11 \mathrm{X} 4 \mathrm{~cm}$, disinfested with $2 \%$ hypochlorite. The substrate used was blotter (Mata borrão) moistened with 2.5 times its weight with distilled water. In order to control the temperature, and placed in a germination chamber (B.O.D.) with constant temperature of $25^{\circ} \mathrm{C}\left(+-3^{\circ} \mathrm{C}\right)$, and photoperiod of 12 hours under fluorescent lamps, as prescribed in RAS (Brazil, 2009). Two variables were evaluated in this test: germination speed index (IVG) and percentage of germination $(\mathrm{G} \%)$. The counting for germinated seeds started on the second day after assembling the test, considering the ones which presented the formation and development of the essential structures of an embryo, demonstrating its ability to produce a normal plant under favorable environmental conditions. The last counting varied between the two species and a five-day sequence without germination was used as the criterion for the closure of the test. The rate of germination was obtained by the formula described by Maguire (1972); the formula was $\Sigma(\mathrm{Dn}) / \Sigma \mathrm{n}$, where $\mathrm{n}$ was the number of seeds that germinated on day $\mathrm{D}$ and $\mathrm{D}$ was the number of days from the beginning of the germination test.

In the field emergence test, the seeds corresponding to each treatment were placed in plastic trays measuring $30 \times 20 \times 07 \mathrm{~cm}$, filled with commercial substrate Vivatto Plus, composed by charcoal grind, pinus peels and peat, according to the manufacturer presenting ph 5.6. The trays identified by treatment and repetition were kept in vegetation house and irrigated three times a day.

The counting of seeds which emerged began on the second day after sowing, being repeated every 48 hours for 30 days, adopting, as emergence criteria, the breakdown of the soil barrier (substrate) and the formation of normal plants (Brazil, 2009). The velocity index of emergence (IVE) was obtained through the formula described by Maguire (1962).

From the daily values of emergence, it was also possible to determine the lengths of aerial parts $(\mathrm{CPA} / \mathrm{cm})$ and plant root $(\mathrm{CR} / \mathrm{cm})$, dry masses of aerial part $(\mathrm{MSPA} / \mathrm{g})$, and total dry mass (MST/g). To obtain the dry mass, the parts of the plants were placed in bags of Kraft paper and dried in an oven with forced air circulation at $65^{\circ} \mathrm{C}+-3$, during 72 hours, then cooled in a desiccator with silica gel and weighed in an analytical scale.

The database was submitted to an analysis of variance (test F) and to the normality test of Shapiro - Wilk. The averages were compared by the Scott-Knott test, with the interval of 5\% significance range, through the computer program $\mathrm{R}$. 


\section{RESULTS}

The values for moisture content (b.u.\%) found in the seeds ranged from $7.1 \%$ to $8.3 \%$ for M. urundeuva in the treatments prior to cryopreservation (ac) and from $7.1 \%$ to $8.4 \%$ for treatments submitted to cryopreservation (dc). In $A$. fraxinifolium seeds, the a.c. values presented averages between $6.3-7.3 \%$, and in d.c. values of $6.3-7.5 \%$.

According to Shapiro test - Wilk, the data showed normality for the residues and according to the obtained results in the analysis of variance the averages were classified as significant $(\mathrm{p}<-0.05)$ (Tables 1), verifying that after the application of the Skott-knott agglomeration test, there were differences in the germination and vigor of seeds, being possible to rank the treatments.

In the analysis of the variable IVG (Table2) in seeds of M. urundeuva, the treatments were separated into five distinct groups with T.P. $(4,095)$ and classified as the treatment which presented the highest average followed by T. $(3,295)$ in the second group, and from T1 to T3 $(2,617-2,610)$ in the third group of averages. The T4 treatment $(2,255)$ was isolated in a fourth group and the treatments with DMSO (T5 to T8), independently of the cryoprotectant concentration were classified in the group of the lowest averages.

For the $A$. fraxinifolium seeds, three groups were formed in the IVG, with T.P. $(3,787)$, the treatment which presented the highest average, when compared to the other treatments, followed by treatments T., T1 and T2 $(4,177-3,666)$ in the second group, and from T3 to T8 $(2,682-2,307)$ with dosages based on sucrose in the highest concentrations and in DMSO in the third group.

The seeds of M. urundeuva and A. fraxinifolium used in the germination tests (G\%), presented, respectively, TP treatments (88 and 86) and T (84 and 83) in the group with highest values followed by treatment T1 (59 and 61). It was possible to verify that for both $M$. urundeuva and $A$. fraxinifolium the treatments were highest sucrose dosages and all DMSO dosages were lower when compared to the T.P and T.

In the IVE, for the two studied species, the formation of three distinct groups was observed. In the M. urundeuva seeds the treatments without immersion in $\mathrm{NL}_{2}$ (TP) and with the direct immersion in $\mathrm{NL}_{2}$ (T.) showed higher averages $(3,687$ and 3,255), when compared to other treatments. The seeds of $A$. fraxinifolium had T.P. $(5,380)$ as the treatment with higher averages than the others, followed by the treatments of T-T3 $(3,522-2,947)$ in the second group and T4-T8 $(2,325-2,230)$ in the third group of averages.

The averages for the percentage of emergence (E\%) in the seeds of M. urundeuva presented treatments T.P. (81) and T. (77) in the group of the highest averages, whereas in $A$. fraxinifolium seeds only T.P. treatment (69) was the one which presented the highest average in the group.

In the aerial part length $(\mathrm{CPA} / \mathrm{cm})$ the results did not present significant differences between the treatments for $M$. urundeuva. In the A. fraxinifolium plants, the formation of two distinct groups occurred, being the highest averages concentrated in the treatments T.P. $(11,73)$, T. $(11,79)$, T4 $(11,73)$ and T5 $(11,79)$.

In the root lengths $(\mathrm{CR} / \mathrm{cm}), \mathrm{T} 1(10,495), \mathrm{T} 2(9,360)$ and $\mathrm{T} 5(12,040)$ formed the group with the highest average values in $M$. urundeuva plants, not following a relationship between the dosages and the root length. And for A. fraxinifolium plants, the largest root lengths were presented in T.P. and T. (11,73 and 11,79). 
The dry masses of the area (MSPA/g), root (MSCR/g) and total dry mass (MST/g) in M. urundeuva plants did not show significant differences among treatments. However, for $A$. fraxinifolium plants it was possible to observe that greater weights were present in TP treatments, and T. in the variable MSPA $(11,277$ and 11,867) and MSCR $(0,115$ and 0,110$)$, and that for total dry mass (MST/g), besides the T. and T.P., the treatment T1 $(0,112)$ also composed the group with the highest averages.

\section{DISCUSSION}

The averages found in the test of the moisture degree of the seeds of M. urundeuva and A. fraxinifolium corroborate with Martins and Pinto (2014), who working with seeds of Handroanthus umbellatus (Sond.), Obtained averages of 6.3\% b.u., and Stegani et al (2017), working with seeds of Sinningia leucotricha (Hoehne) Moor and treating them with protective solutions and cryopreserving than, observed that the water contents of the seeds hybrid presented the highest germination averages where around $7.5 \%$ b.u.

According to José et al. (2009), the water content of the seeds destined for conservation for long periods might be between $3-7 \%$ b.u., without suffering great interferences in the physiological quality of the material. This circumstance can be explained by the fact that seeds stored for months or years usually have desiccation tolerance and are able to maintain their vigor with low water content and, according to Fowler (2000), this reduction in the water content of the seeds may cause the decrease of their metabolic activity, which prolongs their viability.

According to Barrôco et al. (2005), during the germination process, water is seen as a primary factor, because during this stage biochemical processes occur that start from the imbibition of the seed In this research, different contents of those recommended for the studied seeds could influence the treatments both without and with the use of the cryoprotective solutions and immersion in $\mathrm{NL}_{2}$. However, from the drying process in oven with forced air circulation, it was possible to control the seed moisture and to maintain them within the expect levels for those with orthodox behavior.

In the study it was possible to verify that the treatments with direct immersion in $\mathrm{NL}_{2}$ without treatment with cryoprotectants, presented the best results when compared to the other applied cryopreservation protocols.

The treatments with cryoprotectants DMSO and sucrose showed the lowest averages for both IVG and germination percentage $(\mathrm{G} \%)$, when compared to seeds that did not receive cryoprotectants and were immersed in liquid nitrogen, regardless of the species studied and concentration levels. of solutions.

These results corroborate with Araujo (2016), working with Passiflora spp Seeds, treated with different cryoprotectants and cryopreserved in $\mathrm{NL}_{2}$. The best results of IGV and germination percentage (3,3 and 78\% and 2,89 and 70\%) were of Passiflora in these control treatments without immersion in $\mathrm{NL}_{2}$ and without the use of cryoprotectants, as well as with as direct immersion in $\mathrm{NL}^{2}$.

Stegani et al (2017) obtained the best results for germination percentage (57\%) of $S$. leucotricha (Hoehne) Moor seeds cryopreserved directly in $\mathrm{NL}_{2}$. Souza et al (2005) aiming at determining the best conditions and appropriate periods of storage to vigor types of conservation of Tabebuia serratifolia Vahl, to those found in this study for IVG $(3,65)$. 
According to Araujo et al (2016), the use of sugars especially sucrose might stabilize the phospholipids bilayer, acting as an external osmotic agent. When in the absence of water, the sucrose maintains the ability to transport nutrients through the membranes, keeping the lipids in a fluid phase, stabilizing proteins under freezing conditions (Woedlders et al 1997). Nonetheless, for this study, as mentioned above, the two species did not respond according to predicted by the authors, presenting IVG indices classified in superior groups to the DMSO treatments, and composing the group with the best averages with treatments with direct immersion in $\mathrm{NL}_{2}$ and without immersion.

The data obtained on this work for IVE are similar to those found by Araujo et al (2016) moment in which was noticed that for $P$. edulis seed the treatments without immersion in $\mathrm{NL}_{2}$ and without the use of cryoprotectants and with immersion in $\mathrm{NL}_{2}$ presented superior averages of IVE and emergence percentage compare to seeds treated with DMSO or sucrose.

Paiva Sobrinho et al (2017), presented in their studies values that allow a different interpretation from the obtained in this work, because with Genipa americana L. seeds, it was obtained after the treatment with DMSO in the concentration of $11.29 \%$, and emergence percentage of $64,2 \%$, with the vigor of the plants being maintained, and for the treatments with sucrose the values of both IVE and IVG were lower in average values than those with DMSO. In the present study, the DMSO values for the seeds of M. urundeuva A. fraxinifolium in the percentage of emergence were always lower than the control and for seeds without treatment with cryoprotectants.

Zeliang and Pattanayak (2012) and Kuehne and Bhinja (2012) emphasize that the proposed conservation protocols should maintain the viability of biological materials during the freezing/thawing cycle. However, different responses may be obtained with the same protocol depending on the used materials.

Comparing to the average group among the treatments for the studied species, it was verified that as well as for the IVG and germination percentage, the seeds presented the best results from the treatments without cryopreservantion and / or direct immersion in $\mathrm{NL}_{2}$.

In theory, ultra-low temperatures should maintain the quality of the stored tissue, for both compounds such as sucrose and DMSO in different concentrations, as well as the combination of these or other substances, are used successfully in the treatment of various materials to be stored so that there is its protection and possibility of recovery in a period after storage.

The vigor of the studied seeds showed a significant decrease in the IVE and emergence percentage averages, based on the use of DMSO and sucrose solutions. This fact can be explained by studies such as Wu et al (2013), which estate that a high concentration of DMSO, which varies according to the specificities of the studied material, can cause excessive osmotic dehydration and lead to tissues death.

Hirano et al (2009) explain that high sucrose dosages may also decrease seed vigor by excess dehydration once the sucrose solution tends to substitute a part of the water present in the seeds. If it is close to the minimum acceptable to maintain its vigor it will most likely be affected.

The averages for aerial shoot length (CPA) did not show significant differences among treatments for the M. urundeuva plants, corroborating with Galdiano Jr. et al (2012), who used cryoprotectants for the conservation of Dendrobium swartz Dong Yai seeds, in $\mathrm{NL}_{2}$, did not notice significant differences in plant lengths, as well as Garcia and Lima (2000), when carried out vigor tests based on the length of the aerial part of seedlings of Copaifera multijuga 
(Hayne), not proving efficient in detecting differences between stored seeds in different packages in laboratory environment.

In the evaluation of the treatments with sucrose, the dosage of 1,16M (T4), 5\% DMSO (T5) and direct immersion in $\mathrm{NL}_{2}$ (T) showed positive results for CPA in A. fraxinifolium plants, being possible to observe a tendency for a decreasing relationship among the classification of the averages of CPA and the type of applied treatment, in which the highest averages were among cryopreservation without seed cryoprotection and initial dosages of sucrose or DSMO.

In CR, in plants of M. urundeuva T.P. and the 0.58M sucrose (T.2) and 5\% DMSO (T.5) dosages showed the longest lengths, as well as the T.P. in A. fraxinifolium plants. Stegani et al. (2017) obtained the highest mean values for CPA from the control treatment, composed of seeds of $S$. leucotricha cryopreserved in $\mathrm{NL}_{2}$ and without the use of cryoprotective solutions.

Treatments with greater length values of parts or whole normal plants were considered by Vieira and Carvalho (1994) as more vigorous. Such an assertion may be associated with the capacity of the plant for translocation of reserves and greater assimilation of the latter by the embryonic axis, when compared to the smaller ones, in which the cotyledons generally aid in the process by supplying the stored nutrients or photosynthesized to the seedling.

For the variables MSPA, MSR and MST in the M. urundeuva plants they were not differences between the treatments, whereas in the evaluated A. fraxinifolium plants the behavior of the treatments showed higher averages in the Standard Control and Control for MSPA, MSCR. For MST, the treatment with 0.29M (T1) dosage showed the same values as the Standard Witness and Witness.

Goldfarb et al (2010), working with Jatropha curcas seeds, and Souza et al (2005) working with Handroanthus serratifolius (Vahl) seeds verified that in the process of storage at low temperatures the vigor measured by the dry mass of plants was not lost.

Based on the results of dry masses in DMSO treatments at all concentration levels and sucrose levels above $0,29 \mathrm{M}$ (T1), they were not satisfactory, allowing the understanding that the use of cryoprotectants, in this case, may be directly related to the decrease of seed vigor, when referring to these variables, and for the studied species.

In a general context, when comparing the degree of representativeness of the averages for all variables analyzed, treatment with direct immersion in $\mathrm{NL}_{2}(\mathrm{~T})$ for both $M$. urundeuva and $A$. fraxinifolium plants can be understood as an alternative for storage of RGVs, being possible to suppose that in these protocols the conservation of the physical structures of the seed takes place, and as a consequence, maintains the germination and the vigor of that material, when compared to the stage of pre-storage. 


\section{CONCLUSIONS}

In the germination test, germination percentage, and germination speed index it was noticeable the favorable averages for cryopreservation with direct immersion in $\mathrm{NL}_{2}$ for the studied species.

The germination and vigor tests indicated that the storage in $\mathrm{NL}_{2}$ without the use of cryoprotective solution is the most promising, when considering the two studied species.

\section{REFERENCES}

ARAÚJO DS, DA LUZ PB, NEVES, LG, PAIVA SOBRINHO S. Criopreservação de espécies de Passiflora. Journal of Seed Science. v. 38, n. 3, 2016.

BARRÔCO RM, VAN POUCKE K, BERGERVOET JH, DE VEYLDER L, GROOT SP, INZÉ D, ENGLER G. The role of the cell cycle machinery in resumption of postembryonic development. Plant Physiology, v.137: n. 1, p. 127-140, 2005.

BRASIL. MINISTÉRIO DA AGRICULTURA, PECUÁRIA E ABASTECIMENTO. Regras para análise de sementes / Ministério da Agricultura, Pecuária e Abastecimento. Manual. Secretaria de Defesa Agropecuária. Brasília: Mapa/ACS. 2009, 399p.

BRASIL. Instruções para análise de sementes de espécies florestais. Ministério da Agricultura, Pecuária e Abastecimento. Secretaria de Defesa Agropecuária., 2013, 97p.

CARVALHO NM, NAKAGAWA J. Sementes: ciência, tecnologia e produção. 5. ed. Jaboticabal: FUNEP, 2012. 590p.

COSTA CJ. Armazenamento e conservação de sementes de espécies do Cerrado. Planaltina, DF. Embrapa Cerrados: Documento. 2009, 30p.

DECRUSE SW, SEENI S, PUSHPANGADAN P. Effects of cryopreservation on seed germination of selected rare medicinal plants of Índia. Seed Science and Technology. v. 27, n.2, p. 501-505, 1999.

ENGELMANN F. Plant cryopreservation: progress and prospects. In Vitro Cellular e Developmental Biology-Plant. v.47 (1), p 05-16, 2011.

FORZZA R. C, BAUMGRATZ JFA, BICUDO CEM, CANHOS D, CARVALHO JR AA, COSTA AF, COSTA DP, HOPKINS M, LEITMAN PM, LOHMANN LG, LUGHADHA EN, MAIA LC, MARTINELLI G, MENEZES M, MORIM MP, NADRUZ M, PEIXOTO AL, PIRANI JR, PRADO J, QUEIROZ LP, SOUZA VC, STEHMANN JR, SYLVESTRE LS, WALTER BMT, ZAPPI DC. Catálogo de Plantas e Fungos do Brasil. Rio de janeiro: Jardim Botânico do Rio de Janeiro, 2014. vol.2, 870p.

FOWLER JAP. Superação de dormência e armazenamento de sementes de espécies florestais. Comunicação para Transferência de Tecnologia. Colombo, PR: Embrapa Florestas, 2000. p. 77-99.

GALDIANO JUNIOR RF, LEMOS EGM, FARIA RT, VENDRAME WA. Cryopreservation of Dendrobium hybrid seeds and protocorms as affected by phloroglucinol and Supercool X1000. Scientia Horticultura, v.148, p.154-160, 2012.

GARCIA LC, LIMA D. Comportamento de sementes de Copaifera multijuga Hayne durante o armazenamento. Revista Acta Amazônica. v. 30: n.3, p. 369-375, 2000. 
GEMAQUE RCR, DAVIDE AC, DA SILVA EAA, FARIA JMR. Effect of slow and fast drying on Ipê-Roxo seeds (Tabebuia impetiginosa (Mart.) Standl.). Revista Cerne. v. 11, n. 4, p. 329-335-329-335, 2015.

GOLDFARB M, DUARTE MEM, MATA MERMC. Armazenamento criogênico de sementes de pinhão-manso (Jatropha curcas L.) Euphorbiaceae. Revista Biotemas. v.23, p.27-33, 2010. HUEHNE PS, BHINIJA K. Application of cryoprotectants to improve low temperature storage survival of orchid seeds. Scientia Horticulturae, v.135, p.186-193, 2012.

JOSÉ SCBR, SALOMÃO NA, MUNDIM RC, PÁDUA JG. Umidificação de sementes de girassol após ultrassecagem em sílica gel e câmara de secagem. Revista Brasileira de Sementes, v.31: n.3, p.16-26, 2009.

MAGUIRE JD. Speed of germination-aid selection and evaluation for seedling emergence and vigor. Crop Science. v.2: p.176-177, 1962.

MARTINS CC, PINTO MADSC. Armazenamento de sementes de ipê-amarelo-do-brejo (Handroanthus umbellatus (Sond.) Mattos. Bignoniaceae). Ciência Florestal. V.24: n.3, p.533539, 2014.

MARTINS AOBPB. Identificação do perfil químico e avaliação das atividades antioxidante, gastroprotetora, cicatrizante e antimicrobiana do extrato hidroalcoólico das cascas de Astronium fraxinifolium Schott ex. Spreng.(Gonçalavo). Crato-CE: Universidade Regional do Cariri, 2013. 95p. (Dissertação- mestrado em m Bioprospecção Molecular).

MEDEIROS ACS. Armazenamento de sementes florestais. In: SEMANA DO ESTUDANTE UNIVERSITÁRO, 1. Colombo, 2003. Embrapa Florestas-Artigo em anais de congresso. Colombo: Embrapa. p.1-12.

MOLINA TF, TILLMANN MAA, DODE LB, VIÉGAS, J. Criopreservação de sementes de cebola. Revista Brasileira de Sementes, vol. 28, $\mathrm{n}^{\mathrm{o}}$ 3, p.72-81, 2006.

PAIVA SOBRINHO S, DE FIGUEIREDO MC, LUZ PB, NEVES LG, CAMILI EC. Tolerância de sementes de jenipapo a crioprotetores e ao descongelamento após imersão em nitrogênio líquido. Revista Pesquisa Florestal Brasileira. v. 37, n. 92, p. 421-428, 2017.

SAKAI A, KOBAYASHI S, OIYAMA I. Cryopreservation of nucellar cells of navel orange (Citrus sinensis Osb. var. brasiliensis Tanaka) by vitrification. Plant Cell Reports. v. 9: n.1, p.30-33, 1990.

SALOMÃO AN. Respostas de sementes de espécies tropicais a exposição ao nitrogênio líquido. Brazilian Journal of Plant Physiology. v.14: n.2, p.133-138, 2002.

SANTOS IRI, SALOMÃO AN. Manual de curadores de germoplasma - vegetal: criopreservação. Brasília: Embrapa, 2010. v.1, 16p.

SOUZA FBC, MENGARDA LHG, SPADETO C, LOPES JC. Substratos e temperaturas na germinação de sementes de gonçalo-alves (Astronium concinnum Schott). Revista Tropica: Ciências Agrárias e Biológicas. v.6: 76-86, 2012.

STEGANI V, ALVES GAC, BERTONCELLI DJ, FARIA RT. Cryopreservation of seeds of Brazilian edelweiss (Sinningia leucotricha). Ornamental Horticulture. v. 23: n. 1, p. 15-21, 2017.

TRESENA NL, CAVALCANTI MATA MERM, DUARTE MEM. Determinação do teor de água limite para crioconservação das sementes de ipê amarelo (Tabebuia chrysotrica (Mart. Ex. DC.) Standl.). Revista Cerne. v.16: n.2, p.171-175, 2010.

VIEIRA RD, CARVALHO NM. Testes de vigor em sementes. Jaboticabal: FUNEP, 1994. p.49-85. 
WETZEL MVS, REIS RB, RAMOS KM. Metodologia para criopreservação de sementes de espécies florestais nativas. $1^{\circ}$ edição. Brasilia: Embrapa Recursos Genéticos e Biotecnologia (INFOTECA-E), 2003. vol. 1, 5 p.

WOELDERS H, MATHIIJS A, ENGEL B. Effects of trealose, and sucrose, osmolality of the freezing medium, and cooling rate on viability and intractness of sperm after freezing and trawing. Cryobiology. v.35: p.193-195, 1997. 


\section{TABLES}

Table 1. - Medium squares (MC) and percentage coefficients of the experimental variation for tests with seeds of Pantanal forest species cryopreserved in $\mathrm{NL}_{2}$, in which the germination rate index (GI), germination percentage (G\%), Emergence rate index (IVE), emergence percentage (E\%), length (CPA), root length (CR), dry matter of aerial part (MSPA), Dry root mass (MSR) and total dry matter mass (MST).

\begin{tabular}{ccccccccccc}
\hline & \multicolumn{8}{c}{ Variáveis } \\
\cline { 2 - 10 } Species & IVG & $\mathbf{G}$ & $\mathbf{I V E}$ & $\mathbf{E}$ & $\mathbf{C P A}$ & $\mathbf{C R}$ & MSPA & MSR & MST \\
& - & $\mathbf{( \% )}$ & - & $\mathbf{( \% )}$ & $\mathbf{( c m )}$ & $\mathbf{( c m )}$ & $\mathbf{( g )}$ & $\mathbf{( g )}$ & $\mathbf{( g )}$ \\
\hline $\mathrm{A}$ & $4,392 *$ & $1128,040 *$ & $2,223 *$ & $1253,38^{*}$ & $4,252 *$ & $2,861 \mathrm{~ns}$ & $0,001 *$ & $0,008^{*}$ & $0,003 *$ \\
$\mathrm{~B}$ & $6,874 *$ & $493,380 *$ & $10,808 *$ & $802,71 *$ & $19,078^{*}$ & $4,683 *$ & $0,001 *$ & $0,001 *$ & $0,006^{*}$ \\
\hline
\end{tabular}

Subtitle: A- H. chrysotrichus, B- H. impetiginosus. Ns - averagesdo no show significant differences; * averages present significant differences, at the level of $5 \%$ of significance. 
Table 2. Averages for the germination speed index (IVG), germination percentage (G\%), emergence velocity index (IVE), emergence percentage (E\%), aerial part length (CPA), root length (CR), dry matter of aerial part (MSPA), dry root matter mass (MSR) and total dry mass (MST) for seeds and plants of five species of the Pantanal biome cryopreserved in Liquid Nitrogen $\left(\mathrm{NL}_{2}\right)$.

\begin{tabular}{|c|c|c|c|c|c|c|c|c|c|}
\hline F.V. & $\begin{array}{c}\text { IVG } \\
-\end{array}$ & $\begin{array}{c}G \\
(\%)\end{array}$ & $\begin{array}{c}\text { IVE } \\
-\end{array}$ & $\begin{array}{c}E \\
(\%)\end{array}$ & $\begin{array}{l}\text { CPA } \\
\text { (cm) }\end{array}$ & $\begin{array}{l}\text { CR } \\
\text { (cm) }\end{array}$ & $\begin{array}{c}\text { MSPA } \\
\text { (g) }\end{array}$ & $\begin{array}{c}\text { MSCR } \\
\text { (g) }\end{array}$ & $\begin{array}{c}\text { MST } \\
\text { (g) }\end{array}$ \\
\hline & \multicolumn{9}{|c|}{ A-M. urundeuva } \\
\hline T.P. & $4,095 \mathrm{a}$ & $88,000 \mathrm{a}$ & $3,687 \mathrm{a}$ & $81,000 \mathrm{a}$ & $9,415^{\text {ns }}$ & $10,495 \mathrm{a}$ & $0,110^{\mathrm{ns}}$ & $0,122^{\mathrm{ns}}$ & $0,232^{\text {ns }}$ \\
\hline T. & $3,295 b$ & $84,000 \mathrm{a}$ & $3,255 \mathrm{a}$ & $77,000 \mathrm{a}$ & 9,685 & $9,360 \mathrm{~b}$ & 0,107 & 0,112 & 0,222 \\
\hline T1 & $2,617 \mathrm{c}$ & $59,000 \mathrm{~b}$ & $2,705 b$ & $62,000 \mathrm{~b}$ & 9,155 & $8,300 \mathrm{~b}$ & 0.105 & 0,112 & 0,222 \\
\hline $\mathbf{T} 2$ & $2,765 \mathrm{c}$ & $51,000 \mathrm{c}$ & $2,482 b$ & $54,000 \mathrm{c}$ & 12,227 & $11,692 \mathrm{a}$ & 0,107 & 0,115 & 0,220 \\
\hline $\mathbf{T 3}$ & $2,610 \mathrm{c}$ & $41,000 \mathrm{~d}$ & $1,755 \mathrm{c}$ & $50,000 \mathrm{c}$ & 9,407 & $9,727 b$ & 0,110 & 0,115 & 0,225 \\
\hline T4 & $2,255 \mathrm{~d}$ & $38,000 \mathrm{~d}$ & $1,732 \mathrm{c}$ & $44,000 \mathrm{c}$ & 8,617 & $8,180 \mathrm{~b}$ & 0,110 & 0,117 & 0,230 \\
\hline T5 & $1,695 \mathrm{e}$ & $37,000 \mathrm{~d}$ & $1,535 \mathrm{c}$ & $42,000 \mathrm{c}$ & 11,415 & $12,040 \mathrm{a}$ & 0,112 & 0,110 & 0,225 \\
\hline T6 & $1,450 \mathrm{e}$ & $36,000 \mathrm{~d}$ & $1,475 \mathrm{c}$ & $39,000 \mathrm{c}$ & 10,287 & $9,260 \mathrm{~b}$ & 0,105 & 0,107 & 0,212 \\
\hline $\mathbf{T} 7$ & $1,285 \mathrm{e}$ & $36,000 \mathrm{~d}$ & $1,635 \mathrm{c}$ & $40,000 \mathrm{c}$ & 8,400 & $8,067 \mathrm{~b}$ & 0,107 & 0,110 & 0,217 \\
\hline T8 & $1,392 \mathrm{e}$ & $33,000 \mathrm{~d}$ & $1,502 \mathrm{c}$ & $43,000 \mathrm{c}$ & 8,702 & $8,512 b$ & 0,102 & 0,107 & 0,215 \\
\hline CV(\%) & 13,31 & 10,34 & 14,01 & 18,16 & 19,66 & 18,97 & 7,53 & 8,00 & 6,19 \\
\hline
\end{tabular}

\section{B-A. fraxinifolium}

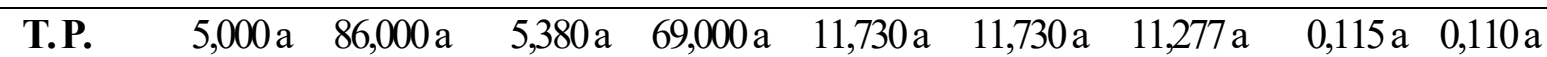

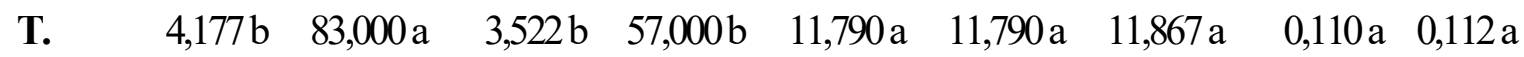

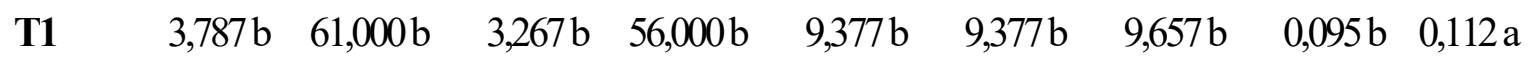

$\begin{array}{llllllllll}\text { T2 } & 3,660 \mathrm{~b} & 43,000 \mathrm{c} & 2,897 \mathrm{~b} & 52,000 \mathrm{~b} & 9,990 \mathrm{~b} & 9,990 \mathrm{~b} & 10,000 \mathrm{~b} & 0,085 \mathrm{~b} & 0,092 \mathrm{~b}\end{array}$

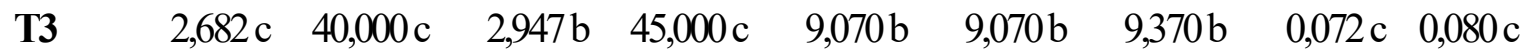




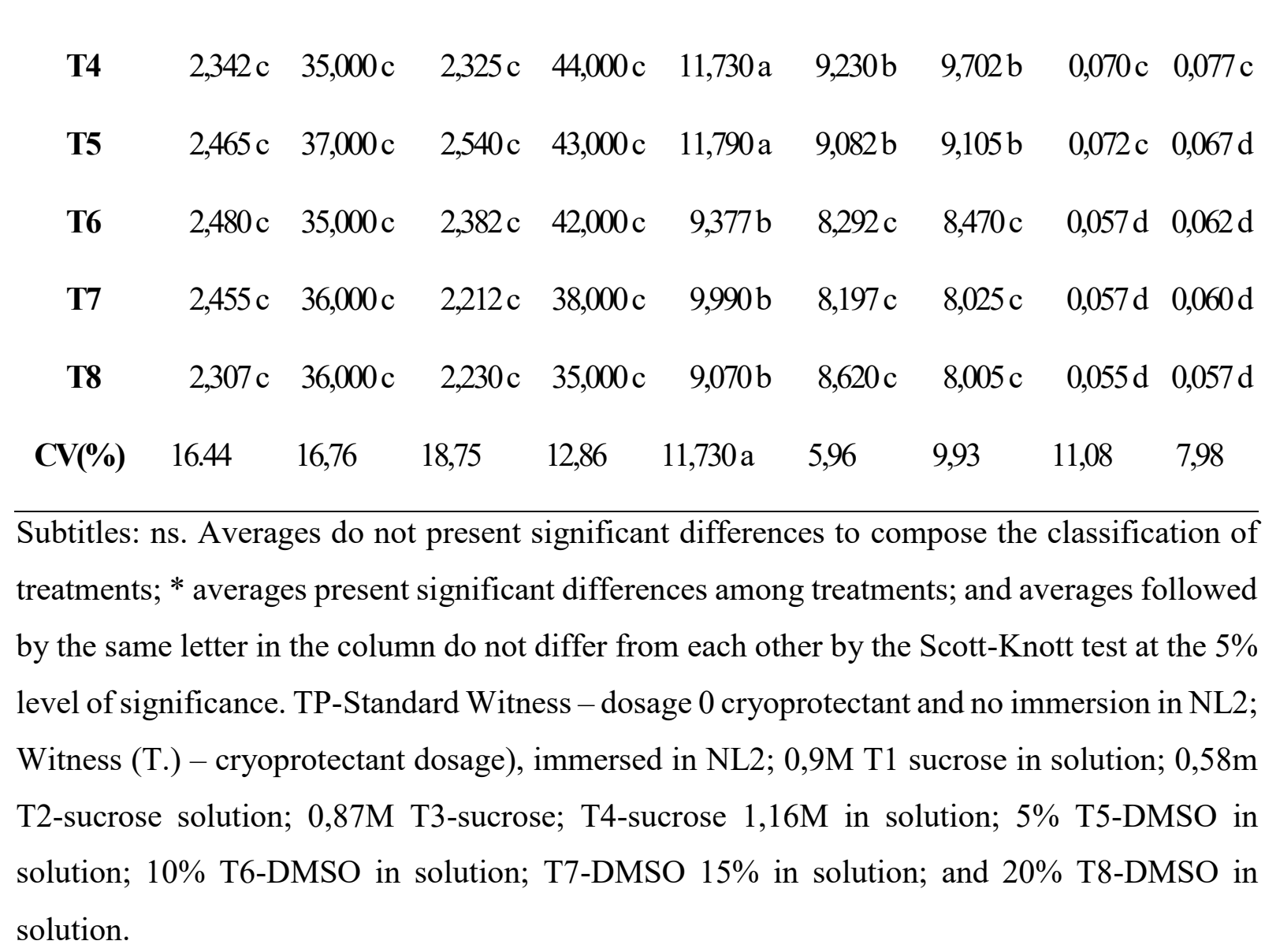

